\section{Unreconstructed man}

SIR - In the process of describing the physical characteristics of class I MHC molecules, which define the type of peptide that can be bound in their central groove, Peter Parham provides some sensational prose (Nature 360, 300-301; 1992). What can he think of women?

$\mathrm{He}$ states that "class I molecules are promiscuous with regard to the peptides they bind . . . (yet are) ... well adapted to any particular partner". Then he gives us "port and cigars" and "fantasy" for gentlemen "before a sampling of their secrets" reveals "that the class I molecule is an intrinsically female structure" to resolve which "a cavalry of crystallographic gentlemen have charged". It is most unfortunate, also, that the tee-hee fraternity refer to this structure as "Bjorkman's groove" (she's a woman, you know).

There is more in his piece but, best of all, with the complicity of Nature, there is a colour picture of a frankly vulval class I molecule filled by a pink penile peptide. If this was just foolish innuendo, I could forgive it as a good dose of tongue in cheek and hope that Parham grows up.

But Parham is wrong. Plugs/sockets and bolts/nuts are good examples of what engineers describe as male/female components in the only sense to which Parham could innocently refer. These components, however, have a low tolerance. They necessarily fit perfectly together in exactly the sense that $\mathrm{MHC} /$ peptide combinations cannot to fit more than one peptide. Although if Parham really is using this analogy he manifests his most extreme chauvinism here by stating that class I grooves are promiscuous and suggesting peptides are not. The slag and the gentleman.

Looking deeper into Parham's groove, I find the most insidious message in the implicit content of this puerile paper. This is a scientist writing about science; he should be painting pictures with an assembly of abstract facts. But his coital metaphor is a rich narrative. He provides a subjective story in which to couch observations - and to anticipate discovery. When do we get the orgasm of T-cell activation? And how many times can it happen? This is science for Naturism not Nature. It cannot be serious.

\section{Harry White}

University College London,

Department of Oncology,

91 Riding House Street,

London W1P 8BT, UK

SIR - I read the News and Views by Peter Parham with mixed feelings. As one studying cellular immune responses during HIV infection, I was gladdened by the progress being made towards understanding the interaction of peptides with MHC class I molecules. On the other hand, I felt vaguely nauseated by the sexual innuendo throughout Parham's commentary. To address this issue is to invite accusation that one is being oversensitive, a poor sport and driven by hormonal imbalances, but I shall take my chances. The picture of Parham and his colleagues sniggering over Van de Wall's representation of the HLA-A2 molecule during seminars is disturbing enough. Benny Hill does immunology? To note that his text must have been approved by Nature is even more disquieting.

\section{Charla Andrews}

\section{Aaron Diamond}

AIDS Research Laboratory,

455 First Avenue, 7th Floor,

New York

New York 10016, USA

SIR - I doubt if I am alone in finding the purple prose peppering Peter Parham's article deeply offensive to the women who read this journal. Are we to understand that crystallography is a Victorian gentleman's club where results are discussed over "port and cigars"? That the class I MHC "is intrinsically a female structure" (whatever that might mean), and that a "cavalry of crystallographic gentlemen have charged" to the task of resolving the shapes of bound peptides? For shame, Dr Parham, this type of prose is badly misplaced in a scientific community that includes women in its membership. No wonder many women scientists feel marginalized when senior colleagues persist in such sexist attitudes.

\section{Lesley A. Bergmeier}

Division of Immunology,

Guy's and St Thomas's Medical Schools, London SE1 9RT, UK

\section{Creative reviews}

SIR - Michael Ignatius ${ }^{1}$ gives convincing statistics to suggest that we have gone "review crazy". As "Tristram Shandy' wrote (1759): "Shall we for ever make new books, as apothecaries make new mixtures, by pouring only out of one vessel into another?" A review that simply collates the conclusions of all relevant papers in journalistic 'bites', sound or unsound, may be little improvement on the computer print-out from an abstracting service. Yet reviewing can be much more than an easy path to publications.

Well-written summaries, distinguish- ing wood from trees, do help researchers, teachers and students. Reviews may also contain new ideas, cover papers in other languages, and show us which dead wood can safely be relegated to history. Some reviews, if that is the right word, draw on information not to be found in abstracts - from older work perhaps, or, to give a biological example, the many quantitative data on normal or control animals that are sometimes only incidental to the research.

As publication of 'minimum publishable units' accelerates, we need more creative reviews, not only to help us cope with the log-jam of new ideas but also to extract the most meaning from all those costly, hard-won data. Some editors discourage such synthesis in 'experimental' papers. Reviewing should not be denigrated: it is bad enough that it lacks the kudos of expensiveness.

Richard F. Burton

Institute of Physiology,

University of Glasgow,

Glasgow G12 8QQ. UK

\section{Future of}

\section{Baer Museum}

SIR - I have just learnt that the Estonian Academy of Sciences intends to suppress the K. E. von Baer Museum, which was created in 1976 in Baer's old house in Tartu, in order to rent the house to a private commercial organization for financial gain. Baer's museum is now a centre for the history of biology, where Baer's scientific papers and correspondence have been and are still collected and analysed (see Nature 353, 104; 1991).

Ironically, the academy was the coorganizer, last February, of a successful international conference commemorating the 200th anniversary of Baer's birth. Baer is rightly considered by the Estonians themselves to be their most famous scientist and his portrait has been chosen to illustrate the new Estonian $\mathrm{Kr} 2$ banknote.

The academy's plan is of course influenced by the critical economic situation of the newly independent republic, but the damage it will cause to future Estonian and international researchers appears to be much greater than the immediate profit it will bring.

I hope concerned scientists will intercede with the president of the Estonian Academy of Sciences (Kohtu 6, EE 0106 Tallinn, Estonia) not to close Baer's Museum.

\section{Jean-Claude Beetschen}

Centre de Biologie du Développement,

Université Paul-Sabatier,

31062 Toulouse,

France

NATURE · VOL 361 · 14 JANUARY 1993 